\title{
TEMPERATURE DEPENDENCE OF THE POTENTIAL OF ZERO CHARGE AT THE MERCURY/POTASSIUM IODIDE AQUEOUS SOLUTION INTERFACE
}

\author{
M.I. SOSA, D. POSADAS and A.J. ARVÍA
}

Instituto de Investigaciones Fisicoquimicas Teóricas y Aplicadas (I.N.I.F.T.A.), Sucursal 4, Casilla de Correo 16, (1900) La Plata (Argentina)

(Received 27th April 1981; in revised form 16th June 1981)

Most published works aim mostly at the determination of the effect of electrolyte concentration on the potential of zero charge, $E_{z}$, while little information is presently available concerning its temperature dependence. Anderson and Parsons [1] performed electrocapillary surface measurements of the KI aqueous solutions at 5,25 and $45^{\circ} \mathrm{C}$. Similar studies have been carried out with sulphonate anions by Parry and Parsons [2]. Grahame [3] measured the thermal coefficients of $E_{\mathrm{z}}$ in $\mathrm{NaF}$ solutions in the $0-85^{\circ} \mathrm{C}$ temperature range by the capacity method. Randles and Whiteley [4] made similar measurements with $0.1 \mathrm{M}$ solutions of $\mathrm{KCl}, \mathrm{NaOH}$ and $\mathrm{K}_{2} \mathrm{SO}_{4}$ in the $15-35^{\circ} \mathrm{C}$ range. Hills and Payne [5] have also analyzed the temperature and pressure effect on double-layer parameters for $0.1 \mathrm{M}$ aqueous solutions of $\mathrm{NaNO}_{3}, \mathrm{NaF}, \mathrm{Na}_{2} \mathrm{SO}_{4}$ and $\mathrm{NaCl}$ at $20^{\circ} \mathrm{C}$ and $30^{\circ} \mathrm{C}$. Minc and Jastrzebska [6] measured the minimum capacity in dilute concentrations of $\mathrm{KBr}, \mathrm{KCl}$ and $\mathrm{KF}$ aqueous solutions. All these measurements, except Grahame's, were carried out keeping both the reference and tested solution at the same temperature. Paik et al. [7] have also studied the temperature effect on $0.1 M$ and $1 M$ aqueous solutions of $\mathrm{KI}, \mathrm{KCl}, \mathrm{KBr}$ and $\mathrm{NaF}$, keeping the reference electrode at $25^{\circ} \mathrm{C}$. These authors found that $E_{\mathrm{z}}$ increases negatively in the order: $\mathrm{F}^{-}<\mathrm{Cl}^{-}<\mathrm{Br}^{-}<\mathrm{I}^{-}$for $0.1 \mathrm{M}$ solutions in accordance with the increasing adsorbability of the anions. However, for $1 M$ solutions, they found that this trend is reversed for $\mathrm{Br}^{-}$and $\mathrm{I}^{-}$ions [7]. In the course of a thorough study of the temperature behaviour of $\mathrm{I}^{-}$ion adsorption on mercury [8], the temperature coefficient of $E_{\mathrm{z}}$ was measured covering a wide range of electrolyte concentrations and, in this case, results were at variance with those of ref. 7 .

The streaming mercury electrode technique described by Grahame [3] was used to measure the potential of zero charge (pzc). The solutions were made up in alkaline permanganate bidistilled water from Baker Reagent salts and were deaerated by bubbling nitrogen in the cell before each run. Experimental details have been reported elsewhere [8]. In order to check the experimental behaviour of the system, a $0.1 \mathrm{M}$ solution of $\mathrm{KCl}$ was measured at $25^{\circ} \mathrm{C}$, and a discrepancy of only $\pm 0.001 \mathrm{~V}$ with Grahame's results was found [3]. 
TABLE 1

Potential of zero charge at $25^{\circ} \mathrm{C}$

\begin{tabular}{lll}
\hline Concentration $/ M$ & $-E_{\mathrm{z}} / \mathrm{V}^{a}$ & $-E_{\mathrm{z}} / \mathrm{V}^{b}$ \\
\hline 0.010 & 0.612 & $0.615 \pm 0.002$ \\
0.025 & 0.638 & $0.638 \pm 0.002$ \\
0.050 & 0.664 & $0.663 \pm 0.002$ \\
0.100 & 0.687 & $0.688 \pm 0.001$ \\
0.200 & 0.715 & $0.716 \pm 0.002$ \\
0.500 & 0.740 & $0.742 \pm 0.001$ \\
\hline
\end{tabular}

Back-integration method.

$b \quad$ Streaming mercury electrode method.

The emf of the isothermal cell:

$\mathrm{Hg}(\mathrm{pzc}) / \mathrm{KI}(\mathrm{c}) / \mathrm{KCl}$ (sat), $\mathrm{Hg}_{2} \mathrm{Cl}_{2} / \mathrm{Hg}$

was measured for six concentrations in the $0.005-0.75 \mathrm{M}$ range and three temperatures $\left(5^{\circ} \mathrm{C}, 25^{\circ} \mathrm{C}, 45^{\circ} \mathrm{C}\right)$. A smoothed $E_{\mathrm{z}}$ vs. $\ln a$ curve was drawn through known values at each temperature and $E_{\mathrm{z}}$ values were read off for intermediate concentrations. The pzc was also determined by the back-integration method from capacity curves [8] using $-1.500 \mathrm{~V}$ (vs. SCE) as the starting pöint. These values are compared with the experimental $E_{\mathrm{z}}$ values in Table 1, being in good agreement. The $E_{\mathrm{z}}$ values obtained by back integration for 12 concentrations in the above-mentioned range at three temperature are given in Table 2 . Using these values, linearly dependent $E_{\mathrm{z}}$ vs. $T$ plots are obtained. For suitable comparison with published data, the $E_{\mathrm{z}}$ value was referred to a reference electrode kept at $25^{\circ} \mathrm{C}$. Neglecting the effect due to the thermal gradient in solution, the difference between $E_{z}$, referred to an electrode kept at the same temperature $T$ as the tested solution and $E_{z}^{0}$ referred to an electrode kept

\section{TABLE 2}

Potential of zero charge at different temperatures

\begin{tabular}{llll}
\hline Concentration $/ M$ & $-E_{\mathrm{z}}\left(5^{\circ} \mathrm{C}\right) / \mathrm{V}$ & $-E_{\mathrm{z}}\left(25^{\circ} \mathrm{C}\right) / \mathrm{V}$ & $-E_{\mathrm{z}}\left(45^{\circ} \mathrm{C}\right) / \mathrm{V}$ \\
\hline 0.005 & 0.591 & 0.580 & 0.577 \\
0.010 & 0.626 & 0.612 & 0.593 \\
0.015 & 0.633 & 0.620 & 0.607 \\
0.025 & 0.645 & 0.638 & 0.620 \\
0.035 & 0.665 & 0.650 & 0.632 \\
0.050 & 0.673 & 0.663 & 0.643 \\
0.075 & 0.691 & 0.678 & 0.658 \\
0.100 & 0.700 & 0.689 & 0.675 \\
0.200 & 0.737 & 0.716 & 0.687 \\
0.350 & 0.750 & 0.730 & 0.709 \\
0.500 & 0.762 & 0.742 & 0.722 \\
0.750 & 0.780 & 0.756 & 0.733 \\
\hline
\end{tabular}




\section{TABLE 3}

Thermal coefficient of the pzc at $25^{\circ} \mathrm{C}$

\begin{tabular}{ll}
\hline Concentration $/ M$ & $\left(\mathrm{~d} E_{\mathrm{z}}^{0} / \mathrm{d} T\right) / \mathrm{mV} \mathrm{deg}^{-1}$ \\
\hline 0.750 & 1.040 \\
0.500 & 0.835 \\
0.350 & 0.835 \\
0.200 & 0.885 \\
0.100 & 0.785 \\
0.075 & 0.735 \\
0.050 & 0.635 \\
0.035 & 0.585 \\
0.025 & 0.521 \\
0.015 & 0.485 \\
0.010 & 0.535 \\
0.005 & 0.485 \\
\hline
\end{tabular}

at $25^{\circ} \mathrm{C}$, is simply due to the entropy change at the reference electrode. Hence, the change of $E_{\mathrm{z}}^{0}$ with temperature $T$ has been evaluated from:

$\mathrm{d} E_{\mathrm{z}}^{0} / \mathrm{d} T=\mathrm{d} E_{\mathrm{z}} / \mathrm{d} T+\mathrm{d} E_{\text {ref }} / \mathrm{d} T$

the thermal coefficient of the reference electrode $\mathrm{d} E_{\text {ref }} / \mathrm{d} T$ being equal to the entropy variation accompanying the electrode reaction $(\Delta S / F)$. The thermal coefficient of the saturated calomel electrode $\left(0.165 \mathrm{mV} \mathrm{deg}{ }^{-1}\right)$ was obtained from deBethune's tables [9]. In Table 3 temperature coefficients of the $E_{\mathrm{z}}^{0}$ are shown for different concentrations at $25^{\circ} \mathrm{C}$. It is clear that $\mathrm{d} E_{\mathrm{z}}^{0} / \mathrm{d} T$ increases with concentration for all the solutions tested. These results when compared with results for other salts $[3,5]$ show that the temperature coefficient of the pzc increases with adsorbability at any concentration. On the other hand, Paik et al. [7] had found that the halide anion adsorbability trend appears not to be valid, as can be seen by comparing their $\mathrm{d} E_{\mathrm{z}}^{0} / \mathrm{d} T$ data for some $1 M$ potassium halide aqueous solutions. They found that the value for potassium iodide is smaller than that of potassium bromide and attempted an explanation of that trend in terms of thermal deorientation of dipoles. The values of $\mathrm{d} E_{\mathrm{z}}^{0} / \mathrm{d} T$ given in Table 3 as well as the value extrapolated to $1 M$ potassium iodide when compared to results of other authors [3-5] are in agreement with the adsorbability trend $\mathrm{F}^{-}<\mathrm{Cl}^{-}<\mathrm{Br}^{-}<\mathrm{I}^{-}$. Therefore, it appears that the temperature coefficient of $E_{\mathrm{z}}^{0}$ follows the well-known adsorbability trend of anions in the whole concentration range.

\section{ACKNOWLEDGEMENT}

I.N.I.F.T.A. is sponsored by the Consejo Nacional de Investigaciones Cientificas y Técnicas, the Universidad Nacional de La Plata and the Comisión de Investigaciones Cientificas (Provincia de Buenos Aires). 


\section{REFERENCES}

1 W. Anderson and R. Parsons, Proceedings of the 2nd International Congress of Surface Activity III, Butterworths, London, 1957, p. 45.

2 J.M. Parry and R. Parsons, Trans. Faraday Soc.. 59 (1963) 241.

3 D. Grahame, R.P. Larsen and M.A. Poth, J. Am. Chem. Soc., 71 (1949) 2978; D. Grahame. E.M. Coffin and J. Cummings, Tech. Rep. No. 2 to ONR, 11 Aug. 1959: D. Grahame. J. Am. Chem. Soc., 79 (1957) 2093.

4 J.E. Whiteley and J.E.B. Randles, Trans. Faraday Soc., 52 (1956) 1509.

5 G.J. Hills and R. Payne, Trans. Faraday Soc., 61 (1965) 326.

6 S. Minc and J. Jastrzebska, Electrochim. Acta, 10 (1965) 965.

7 W. Paik, T. Andersen and H. Eyring, J. Phys. Chem., 71 (1967) 1891.

8 M.I. Sosa, Doctoral Thesis, Universidad Nacional de La Plata, La Plata, 1980.

9 A.J. deBethune, T.S. Licht and N. Swendemann, J. Electrochem. Soc., 106 (1959) 616. 